\title{
Global English in the Humanities? A Longitudinal Citation Study of Foreign- Language Use by Humanities Scholars
}

\section{Charlene Kellsey and Jennifer E. Knievel}

The authors counted 16,138 citations within 468 articles found in four journals from history, classics, linguistics, and philosophy in the years 1962, 1972, 1982, 1992, and 2002 in order to identify trends in foreignlanguage citation behavior of humanities scholars over time. The number of foreign-language sources cited in the four subjects has not declined over time. Consistent levels of foreign-language citation from humanities scholars indicate a need for U.S. research libraries to continue to purchase foreign-language materials and to recruit catalogers and collection development specialists with foreign-language knowledge.

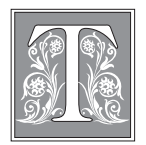

he current study investigates whether declines in college enrollment in foreign languages are reflected in concomitant declines in the use of foreign-language sources by humanities scholars. The answer to this question has collection development implications for research libraries. With library materials budgets losing purchasing power in real terms over time, and the recent, more drastic cuts many libraries have had to make because of a difficult economic environment, it is tempting to assume that foreign books and journals receive less use and could be cut. Although this may be true for undergraduates, collecting decisions based on assumptions about lower use of foreign-language materials by scholars should be supported by data. The purpose of this study is to collect enough data over a sufficient period of time to be able to determine whether a trend of lower use of foreign-language resources has, indeed, developed.

The foreign-language education community has documented a sharp decline since the 1960s in the percentage of college undergraduates studying languages, most severely in the 1980s, from a high of 16.5 per 100 students in 1965 to 7.9 in $1998 .{ }^{1}$ Contributing to this decline was the drop in numbers of colleges with language entrance and/or graduation requirements. ${ }^{2}$ Similar studies also noted steep declines in the proportional numbers of college students taking French and German, the most commonly used non-English lan-

Charlene Kellsey is Assistant Professor and Humanities Monographic Cataloger at the University of Colorado at Boulder; e-mail: Charlene.kellsey@colorado.edu. Jennifer E. Knievel is Assistant Professor and Humanities Reference and Instruction Librarian at the University of Colorado at Boulder; e-mail: Jennifer. knievel@colorado.edu. The authorswould like to thank Keith Gresham, Scott Seaman, Anna Ferris, David Ferris, Joseph Yue, and M. Winslow Lundy for their comments on this paper. 
guages for humanities scholarship, versus large gains in the proportion taking Spanish. In 1998, the latest year for which data are available, Spanish had 55 percent of the total modern language registrations, French had 16.7 percent, and German had only 7.5 percent. $^{3}$ Anecdotal evidence also indicates a decline in the number of students entering graduate studies with the requisite language skills for research in their fields. ${ }^{4}$ Although not all graduate programs in the humanities still require two languages, most require at least one; and the fact that fewer undergraduate students are taking French - and German, especially - may mean that they have to take intensive courses while in graduate school in order to pass the language exams. Inevitably, students can develop less fluency in a short time than when spread over a number of years of high school and undergraduate study. Has this decline in language study affected the use of European-language sources by more recent U.S. humanities scholars in their published scholarly work?

\section{Literature Review \\ Background}

For investigating use of language materials, a good starting point is the literature review by Paul Metz. He noted that Kent's Pittsburgh study found that English-language material represented 91.2 percent of circulation from 1969 to 1973. A Library of Congress study in 1977 found that 87.7 percent of monographs and 92.5 percent of serials used were in English. ${ }^{5}$ In her study of seventy-two Association of Research Libraries (ARL) members in 1985 and 1989, Anna H. Perrault discovered that although in 1985 English and foreign imprints had a nearly equal share of titles purchased, by 1989 foreign imprints had declined to 39 percent of the total. ${ }^{6}$ Circulation studies and acquisition studies, however, though important for learning about the state of European-language sources in U.S. libraries, do not indicate what humanities scholars actually use in their work.

A broader study by W. J. Hutchins, L. J. Pargeter, and W. L. Saunders used several ways of measuring, according to their subtitle, "the place of foreign language materials in the research activity of an academic community." Using the University of Sheffield in England as a case study, they sampled the book collection and articles in the journal collection. They also counted a year's circulation of materials (from checkout slips) by department of the borrower, items on loan on one particular date, and items requested on interlibrary loan. A survey of in-house use of journal articles and a citation analysis also were conducted. Although the wealth of data reported in their study cannot be included here, several items in their results are relevant to the present study. Items borrowed by humanities faculty (excluding modern language departments) over the course of a year were found to be 81.5 percent in English, 4.3 percent in French, 4.2 percent in German, and 5.6 percent in Latin or Greek, with other languages under 1 percent (number of borrowers =69). Their citation analysis looked at fifty-one publications and a total of 5,017 citations and found that 61.7 percent were to English publications. The average number of foreign-language citations per publication (which included books, articles, and theses) was 18.8 and the most-cited languages were German (11.4 $\%)$, French (5.35\%), Spanish (0.75\%), and Italian $(0.4 \%)^{7}$

\section{Citation Analysis}

The literature of citation analysis is abundant, but that dealing with the work of humanities scholars is more limited, in part due to the preponderance of 
monographs as cited sources and to the difficulties of counting citations in the humanities, as the authors of this study discovered. (See the methodology and discussion sections below.) Although many of the humanities citation studies deal with format (monographs versus serials) and age of the source cited, few look at the language of the citation. One example is the recent study by Jennifer Wolfe Thompson, which confirms the dominance of the monograph in citations in literary studies but does not mention language of the citations. ${ }^{8}$

A good source on citation analysis in general is Robert N. Broadus, who discussed the validity of citation studies and reviewed some relevant ones. ${ }^{9}$ John Cullars found that in their monographic works, English-speaking scholars of foreign literature cited 20 percent French sources, 10 percent German, 8 percent Italian, 3 percent Latin, and 1 percent Spanish. ${ }^{10}$ However, Cullars's study looked at a field where one would expect citation of foreign-language sources because of the subject of study.

Studies of the specific humanities fields included in the current study are rare. Jean-Pierre V. M. Herubel and Edward A. Goedeken surveyed The American Historical Review from 1896 to 1990 but looked only at trends in the contents, not sources cited. ${ }^{11}$ Herubel also looked at three other journals in history over time and included a table of the number of foreign-language citations per journal, but not as a percentage of total citations. ${ }^{12}$ M. Sara Lowe's study looked at citations in The American Historical Review at twenty-year intervals from 1950, but because she looked at only one issue for each year, her results appear to be random. ${ }^{13}$

Ylva Lindholm-Romantschuk and Julian Warner included philosophy in their study, using the Arts \& Humanities Citation Index, and Michael Bowman included linguistics and history in his review of previous studies, but both of these works focused on format of the citation (monograph versus serial). ${ }^{14,15}$ Benny Ray Tucker examined citations in two volumes of Transactions of the American Philological Association (a classics annual) but also focused on format and on identifying the most-cited journals. ${ }^{16}$ Thus, there are only a few mentions of language in the literature of citation analysis in the humanities and none that examine the use of foreign-language citations over a period of time.

As the Hutchins, Pargeter, and Saunders study suggests, a number of methods are available for investigating the question of foreign-language use by humanities scholars. However, the need to gather data for a period of several decades in order to document change over time limited those that would be practicable or even possible. Probably no libraries have circulation records going back more than a few years, and sampling collections by publication dates would be seriously affected by libraries' budget vagaries over that period of time. The most practical data collection method seemed to be a citation analysis of representative journal titles because publications for the whole time period are readily available.

\section{Methodology}

\section{Journals Selected for Analysis}

This study focuses on one journal in each of four fields in the humanities: history, philosophy, classics, and linguistics. These fields were chosen to represent a variety of research approaches in the humanities. Because the fields of literature are language specific, we did not include a literature field. Although humanities scholars use monographs more heavily than journals, there did not seem to be a way to provide consistency over time by selecting individual monographic titles. 
Therefore, the authors decided to select a well-known and respected journal title for each of the fields examined and for which issues were available for at least forty years. Only English-language journals published in the United States were considered for inclusion in this study because its focus was U.S. scholars. Although it seems likely that a certain number of articles published in U.S. journals could be by foreign scholars, in point of fact, while counting citations it was apparent that the vast majority of authors were from U.S. universities and colleges. Great attention was given to choosing broadly defined journals covering many or most subfields in their disciplines, rather than niche journals that might carry a determined orientation in the language of source material. For example, the journal French Historical Studies would not have been appropriate because of its obvious language relationship and narrow subject focus.

In history, the authors chose to study the American Historical Review, the journal chosen to represent history in several other citation analysis studies. ${ }^{17,18}$ According to the Journal Citation Reports (JCR) impact factor analysis, the American Historical Review also is the indisputable leader in impact among history journals with broad subject coverage and a U.S. imprint. ${ }^{19}$

In the other three subjects, the choice of journal was not as obvious because the remaining subjects are not evaluated by JCR and no comparable analysis to JCR is available from Arts and Humanities Citation Index. In philosophy, the authors chose the Journal of Philosophy. Hans E. Bynagle described the Journal of Philosophy as "one of the most widely circulated philosophical journals ... varying considerably in content." ${ }^{20}$ Further support of this choice is the description of philosophy journals by Cullars, in which he explained that topics cover "virtually all areas of philosophy." The Journal of Philosophy is the only U.S. imprint journal that earns this description in his "General Philosophy" section. ${ }^{21}$

In linguistics, the authors chose the journal Language. Anna L. DeMiller described Language as "a major scholarly, general linguistics journal." 22 A. J. Nederhof and R. A. Zwaan's extensive survey indicated a list of core linguistics journals, and Language is one of only two in that list that met the selection criteria for this study. ${ }^{23}$

In classics, the authors chose the American Journal of Philology. Fred W. Jenkins described the American Journal of Philology as "one of the oldest and best classical journals published in America." ${ }^{24}$ It was the best choice of U.S. imprint journals that was broad in both its treatment of the subject and its target audience.

\section{Citation-counting Criteria}

The authors counted all citations for the complete volume from each of the following years: 1962, 1972, 1982, 1992, and 2002. This gave data over five decades, ending with the most recent and complete volumes available and beginning with a year prior to the documented declines in foreign-language registrations. Numbers of issues per volume varied among the journals from four to twenty-six; however, the number of articles per volume ranged between fourteen and thirty-two. The total number of articles per entire journal was more consistent, varying only from 106 to 134 , making these four journals a reasonable set to compare. A total of 16,138 citations in 468 articles were included for analysis in this study. Citations were counted and entered into spreadsheets, which were used to calculate totals and percentages of all data. Most of the journals' back issues were available in full text online via JSTOR or a similar aggregator. 


\begin{tabular}{|c|c|c|c|c|c|c|c|}
\hline \multicolumn{8}{|c|}{$\begin{array}{c}\text { TABLE } 1 \\
\text { History: American Historical Review }\end{array}$} \\
\hline $\begin{array}{l}\text { Volume } \\
\text { and Year }\end{array}$ & $\begin{array}{l}\text { English } \\
\text { Citations }\end{array}$ & $\begin{array}{c}\text { Total } \\
\text { Foreign } \\
\text { Citations }\end{array}$ & $\begin{array}{c}\text { Total } \\
\text { Citations }\end{array}$ & $\begin{array}{c}\text { Total } \\
\text { \# of } \\
\text { Articles }\end{array}$ & $\begin{array}{c}\text { \# of Articles } \\
\text { without } \\
\text { Foreign } \\
\text { Citations }\end{array}$ & $\begin{array}{c}\text { Average } \\
\text { Foreign } \\
\text { Citations } \\
\text { per Article }\end{array}$ & $\begin{array}{c}\text { Average } \\
\text { Total } \\
\text { Citations } \\
\text { per Article }\end{array}$ \\
\hline v. $68 ; 1962$ & $588(69.8 \%)$ & $255(30.2 \%)$ & 843 & 24 & $14(58.3 \%)$ & 10.6 & 35.1 \\
\hline v. $77 ; 1972$ & $651(71.6 \%)$ & $258(28.4 \%)$ & 909 & 17 & $5(29.4 \%)$ & 15.2 & 53.5 \\
\hline v. $87 ; 1982$ & $1,702(86.2 \%)$ & $273(13.8 \%)$ & 1,975 & 19 & $9(47.3 \%)$ & 14.4 & 103.9 \\
\hline v. $97 ; 1992$ & $1,197(66.3 \%)$ & $609(33.7 \%)$ & 1,806 & 27 & $9(33.3 \%)$ & 22.6 & 66.9 \\
\hline v. $107 ; 2002$ & $1,570(80.5 \%)$ & $381(19.5 \%)$ & 1,951 & 19 & $8(42.1 \%)$ & 20.1 & 102.7 \\
\hline Total & $5,708 \quad(76.3 \%)$ & $1,776(23.7 \%)$ & 7,484 & 106 & $45(42.4 \%)$ & 16.8 & 70.6 \\
\hline
\end{tabular}

When possible, the online versions were used to count citations.

Some researchers have successfully used Arts and Humanities Citation Index or A\&H Search to count citations for other studies. ${ }^{25}$ However, this method was not effective for this study because A\&H Search generally includes only the names of authors and the cited journal or book, but not the title of the article or book chapter itself, which may be in a different language than the larger title. For this reason, language is indeterminable via A\&H Search, and the authors chose hand-counting as the method of citation analysis. To check the accuracy of citation counts, selected A\&H Search citation totals were compared to counts collected for this study. Predictably, the authors counted slightly fewer citations than A\&H Search because some citations excluded from the study were included in A\&H Search totals.
Categories of citations included were books and journals in English, German, French, Italian, Spanish, Portuguese, and Latin. All other language materials were grouped into "Other Language Books" and "Other Language Articles." Book chapters and dissertations were counted as books. Translations were counted as books or articles in the language into which they were translated because this study's interest is in the language of materials researchers are using. Many researchers cited sources as both journal articles and reprinted book chapters. In these cases, the authors made every effort to determine which version the researcher used as a source and counted that version for the purposes of the citation analysis. Citations excluded from this citation analysis were newspapers, reviews, unpublished manuscripts, presentations, Web sites, and source documents the article was evaluating. Articles that were responses to

\begin{tabular}{|c|c|c|c|c|c|c|c|}
\hline \multicolumn{8}{|c|}{$\begin{array}{c}\text { TABLE } 2 \\
\text { Classics: American Journal of Philology }\end{array}$} \\
\hline $\begin{array}{l}\text { Volume } \\
\text { and Year }\end{array}$ & $\begin{array}{c}\text { English } \\
\text { Citations }\end{array}$ & $\begin{array}{l}\text { Total Foreign } \\
\text { Citations }\end{array}$ & $\begin{array}{c}\text { Total } \\
\text { Citations }\end{array}$ & $\begin{array}{c}\text { Total } \\
\text { \# of } \\
\text { Articles }\end{array}$ & $\begin{array}{c}\text { \# of Articles } \\
\text { without } \\
\text { Foreign } \\
\text { Citations }\end{array}$ & $\begin{array}{c}\text { Average } \\
\text { Foreign } \\
\text { Citations } \\
\text { per Article }\end{array}$ & $\begin{array}{c}\text { Average } \\
\text { Total } \\
\text { Citations } \\
\text { per Article }\end{array}$ \\
\hline v. $83 ; 1962$ & $215(54.6 \%)$ & $179(45.4 \%)$ & 394 & 23 & $1(4.3 \%)$ & 7.8 & 17.1 \\
\hline v. $93 ; 1972$ & $285(52.1 \%)$ & $262(47.9 \%)$ & 547 & 32 & $2(6.2 \%)$ & 8.2 & 17.1 \\
\hline v. $103 ; 1982$ & $301(55.6 \%)$ & $240(44.4 \%)$ & 541 & 26 & $0(0.0 \%)$ & 9.2 & 20.8 \\
\hline v. $113 ; 1992$ & $661(69.1 \%)$ & $295(30.9 \%)$ & 956 & 28 & $2(7.1 \%)$ & 10.5 & 34.1 \\
\hline v. $123 ; 2002$ & $789(79.2 \%)$ & $207(20.8 \%)$ & 996 & 25 & $0(0.0 \%)$ & 8.3 & 39.8 \\
\hline Total & $2,251(65.6 \%)$ & $1,183(34.4 \%)$ & 3,434 & 134 & $5(3.7 \%)$ & 8.8 & 25.6 \\
\hline
\end{tabular}




\begin{tabular}{|c|c|c|c|c|c|c|c|}
\hline \multicolumn{8}{|c|}{$\begin{array}{c}\text { TABLE } 3 \\
\text { Linguistics: Language }\end{array}$} \\
\hline $\begin{array}{l}\text { Volume } \\
\text { and Year }\end{array}$ & $\begin{array}{l}\text { English } \\
\text { Citations }\end{array}$ & $\begin{array}{c}\text { Total } \\
\text { Foreign } \\
\text { Citations }\end{array}$ & $\begin{array}{c}\text { Total } \\
\text { Citations }\end{array}$ & $\begin{array}{c}\text { Total } \\
\text { \# of } \\
\text { Articles }\end{array}$ & $\begin{array}{c}\text { \# of Articles } \\
\text { without } \\
\text { Foreign } \\
\text { Citations }\end{array}$ & $\begin{array}{c}\text { Average } \\
\text { Foreign } \\
\text { Citations } \\
\text { per Article }\end{array}$ & $\begin{array}{c}\text { Average } \\
\text { Total } \\
\text { Citations } \\
\text { per Article }\end{array}$ \\
\hline v. $38 ; 1962$ & $125(56.5 \%)$ & $96(43.4 \%)$ & 221 & 22 & $8(36.4 \%)$ & 4.4 & 10.0 \\
\hline v. $48 ; 1972$ & $526(77.1 \%)$ & $156(22.8 \%)$ & 682 & 33 & $17(51.5 \%)$ & 4.7 & 20.7 \\
\hline v. $58 ; 1982$ & $712(92.2 \%)$ & $60(7.7 \%)$ & 772 & 21 & $10(47.6 \%)$ & 2.9 & 36.8 \\
\hline v. $68 ; 1992$ & $742(95.7 \%)$ & $33(4.2 \%)$ & 775 & 14 & $3(21.4 \%)$ & 2.4 & 55.4 \\
\hline v. $78 ; 2002$ & $944(89.6 \%)$ & $109(10.3 \%)$ & 1,053 & 16 & $5(31.2 \%)$ & 6.8 & 65.8 \\
\hline Total & $3,049(87.0 \%)$ & $454(12.9 \%)$ & 3,503 & 106 & $43(40.5 \%)$ & 4.3 & 33.0 \\
\hline
\end{tabular}

previous articles or conference previews were not analyzed.

Many complications arose during counting. Unlike most journal articles in the sciences, articles in the humanities usually included their citations only in discursive footnotes or within the text itself, making citation-counting more difficult. Only the most recent volumes in linguistics and classics separated the citations into a bibliography at the end of the article, and in the cases of philosophy and history, the citations are still included only in discursive footnotes. Moreover, citations were sometimes incomplete, abbreviated, or nonstandard, particularly in the field of classics, which made determining the language of the source very difficult. In cases of incomplete or in-text-only citations, the authors made every effort to determine the language of the source based on the available informa- tion; in classics, an abbreviations dictionary for journal and reference source titles was very helpful. ${ }^{26}$

\section{Results}

Though the data collected for this study yielded many interesting results, the focus of this article is the usage of foreign-language sources. Contrary to our expectations upon beginning this study, the data do not show a consistent trend of either increasing or decreasing usage of foreign-language sources. Philosophy and classics were equally extreme in their lack, or inclusion, of foreign citations. The extremity of those two data sets was somewhat tempered by the more moderate usage of English and foreign citations in both linguistics and history. See tables $1,2,3$, and 4 for total citation counts in history, classics, linguistics, and philosophy, respectively.

\begin{tabular}{|c|c|c|c|c|c|c|c|}
\hline \multicolumn{8}{|c|}{$\begin{array}{c}\text { TABLE } 4 \\
\text { Philosophy: Journal of Philosophy }\end{array}$} \\
\hline $\begin{array}{l}\text { Volume } \\
\text { and Year }\end{array}$ & $\begin{array}{l}\text { English } \\
\text { Citations }\end{array}$ & $\begin{array}{c}\text { Total } \\
\text { Foreign } \\
\text { Citations }\end{array}$ & $\begin{array}{c}\text { Total } \\
\text { Citations }\end{array}$ & $\begin{array}{c}\text { Total } \\
\text { \# of } \\
\text { Articles }\end{array}$ & $\begin{array}{c}\text { \# of Articles } \\
\text { without } \\
\text { Foreign } \\
\text { Citations }\end{array}$ & $\begin{array}{c}\text { Average } \\
\text { Foreign } \\
\text { Citations } \\
\text { per Article }\end{array}$ & $\begin{array}{c}\text { Average } \\
\text { Total } \\
\text { Citations } \\
\text { per Article }\end{array}$ \\
\hline v. $59 ; 1962$ & $121(90.3 \%)$ & $13(9.7 \%)$ & 134 & 30 & $27(90.0 \%)$ & 0.4 & 4.5 \\
\hline v. $69 ; 1972$ & $212(98.6 \%)$ & $3(1.4 \%)$ & 215 & 23 & $21(91.3 \%)$ & 0.1 & 9.3 \\
\hline v. $79 ; 1982$ & $258(99.2 \%)$ & $2(0.7 \%)$ & 260 & 18 & $16(88.8 \%)$ & 0.1 & 14.4 \\
\hline v. $89 ; 1992$ & $417(96.9 \%)$ & $13(3.0 \%)$ & 430 & 27 & $24(88.8 \%)$ & 0.5 & 15.9 \\
\hline v. $99 ; 2002$ & $676(99.7 \%)$ & $2(0.3 \%)$ & 678 & 24 & $21(87.5 \%)$ & 0.1 & 28.3 \\
\hline Total & $1,684(98.1 \%)$ & $33(1.9 \%)$ & 1,717 & 122 & $109(89.3 \%)$ & 0.3 & 14.1 \\
\hline
\end{tabular}




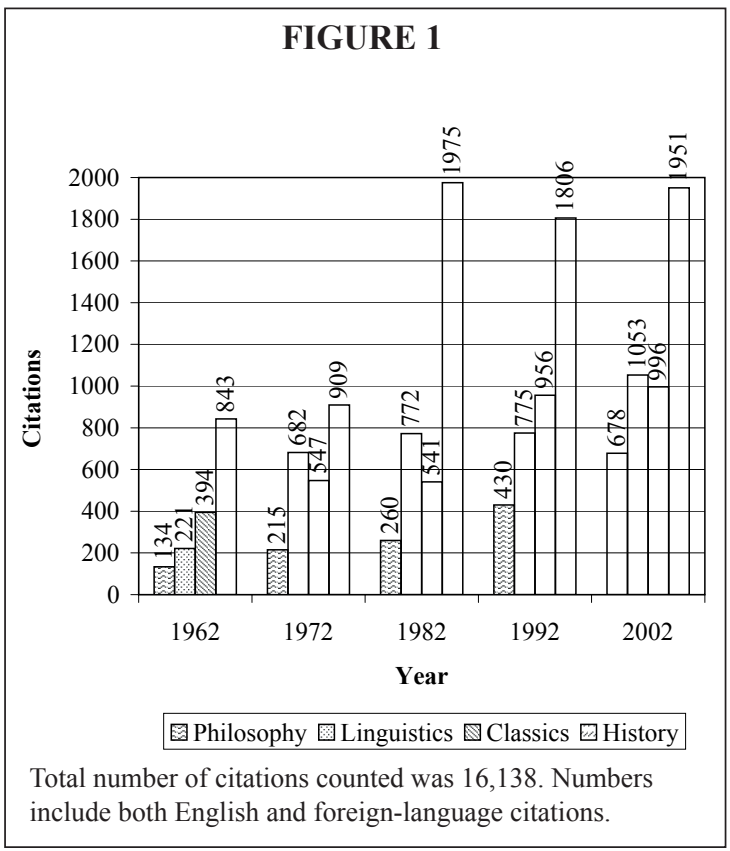

The most consistent trend over all disciplines was the dramatic increase in the number of total citations. (See figure 1.) Most noticeable is the jump in citations in history, which rose 54 percent from 1972 to 1982 alone and 57 percent from 1962 to 2002. Linguistics saw dramatic jumps in total citations in 1972 and again in 2002. Total citations in classics climbed 43 percent from 1982 to 1992 alone, and even philosophy, which consistently had the fewest citations, rose 80 percent over the course of the entire study.

Although foreign citations declined over time as a percentage of total citations, this does not actually reflect a decreased use of foreign sources. Rather, a decreasing percentage of foreign citations reflects only the increase in total numbers of citations. In actual numbers, foreign citations did not de- crease over time but, in fact, increased. (See figure 2.) As shown in tables 1 through 3, the average number of foreign citations in each article showed a modest increase in linguistics and classics (from 4.4 to 6.8 and from 7.8 to 8.3 , respectively), and nearly doubled in history from 10.6 to 20.1. The only field in which the average number of foreign citations did not rise was philosophy. As shown in table 4 , in philosophy the average number of foreign citations per article was consistently below one, reflecting a near absence of foreign-language citations in philosophy articles over time.

Another measure of actual use of foreign citations is how many articles are published in the disciplines without any foreign citations at all. The authors expected this number to rise in all four fields over time, reflect-

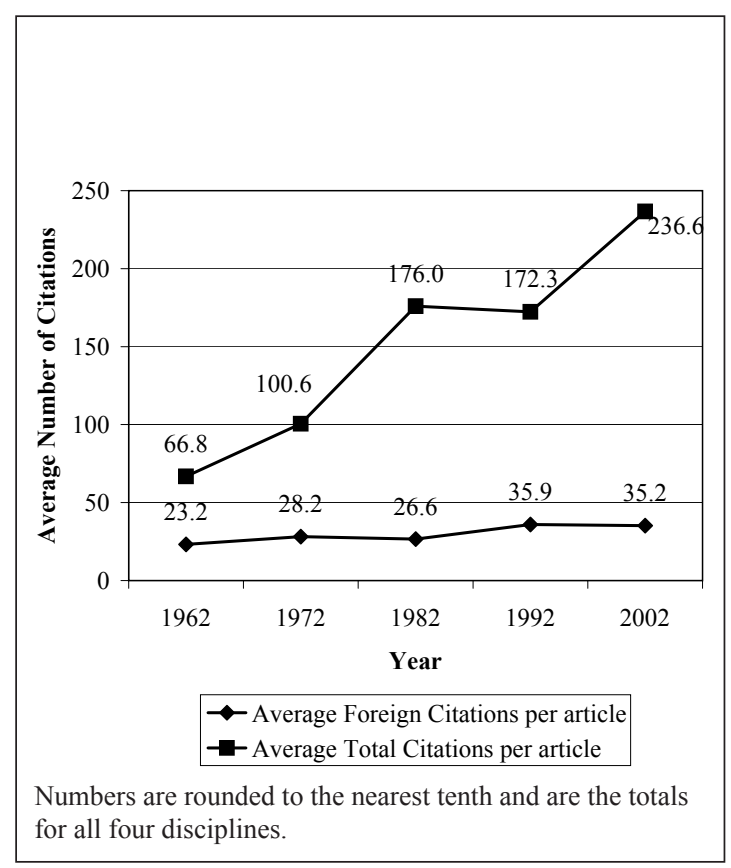




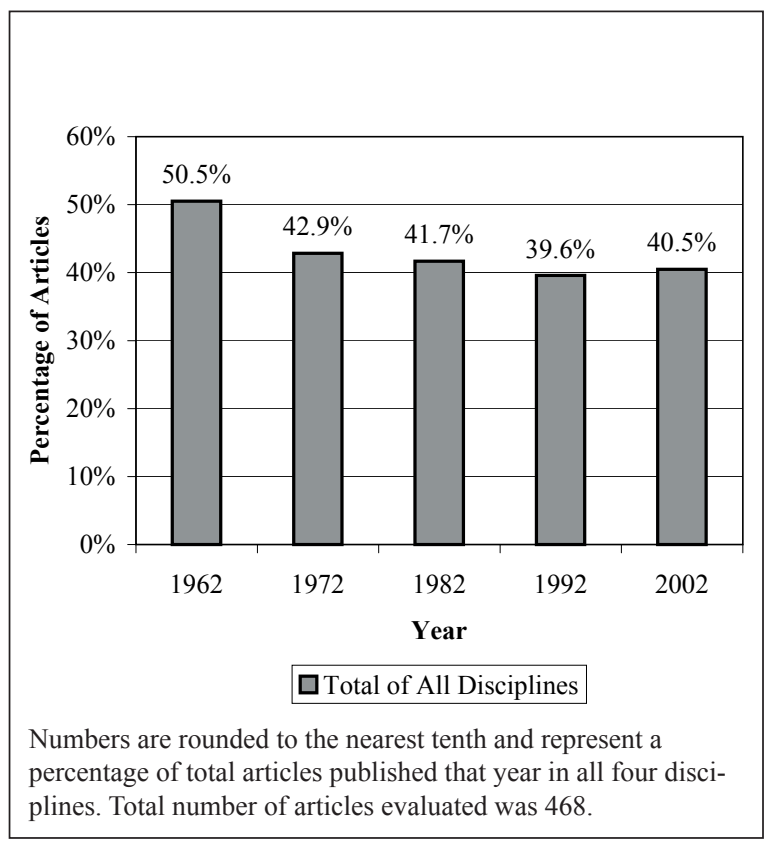

but surprising, decrease in the number of articles with English-only citations, dropping from 90.0 to 87.5 percent over the course of the study. (See table 4.) Figure 3 provides a summary over time of articles in all four disciplines without any foreign citations. The percentage of articles excluding foreign citations was lower in 1992 and 2002 than all the previous years of the study, showing an actual increase in the number of scholars using foreign sources in their research.

Finally, of interest to this study, was the distribution of foreign-language sources.

ing an overall increase in the number of scholars who avoid foreign languages altogether, but there was no consistent trend. The number of articles without any foreign citations varies among disciplines. History actually went down over time (table 1), showing a rise in the number of scholars including foreign languages in their citations. Nearly 60 percent of articles published in history in 1962 were published without any foreign citations, whereas only 42.1 percent of articles in history were published without foreign citations in 2002. In linguistics, the number of articles citing foreign sources went up in the middle of the study but dropped again by the end. (See table 3.) In classics, the number of articles excluding any foreign citations was consistently low, ranging from zero to a high of two articles per volume without foreign citations. (See table 2.) Even in philosophy, where use of foreign citations consistently approached zero, there was a small,

Over all years and all disciplines of the study, English represented 78.6 percent of all citations and foreign citations represented 21.3 percent of all citations. (Percentages are rounded to the nearest tenth.) Of the foreign languages, German and French were the dominant cited languages with 7.8 and 5.7 percent of the total

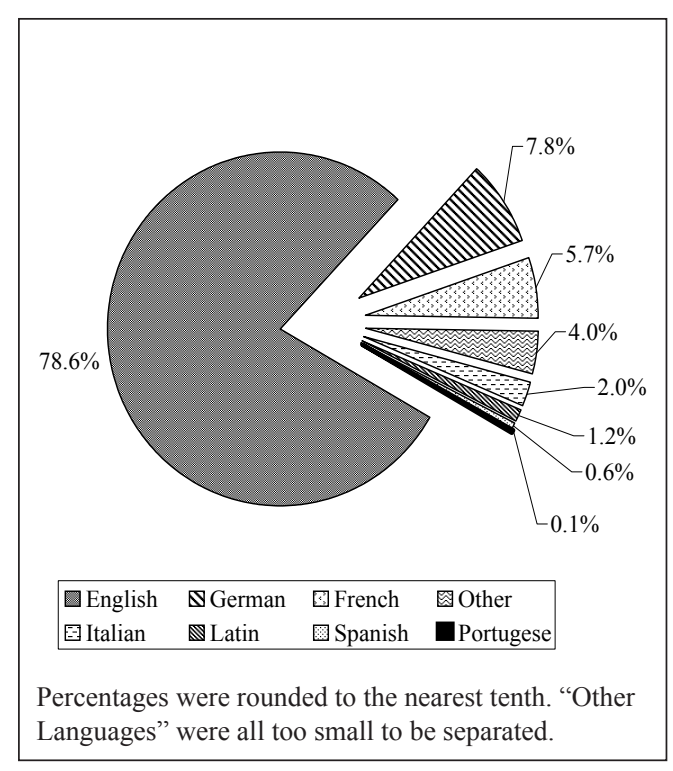


citations, respectively. (See figure 4.) The next most commonly cited language was Italian with 2.0 percent, only a third of the French citations. All other languages tracked were minimal. The "Other Languages" category included many different languages that were generally used extensively in one or two articles in the entire study, including Dutch, Russian, and Polish.

\section{Discussion}

Several broad implications emerge from the results of this study. First, the average number of foreign-language citations per article is higher in 2002 than in 1962 for classics, history, and linguistics; only philosophy shows a decline. Contrary to the authors' expectations, the number of scholars using foreign citations appears to be going up because the number of articles with no foreign citations at all has declined in all four fields. This trend suggests a continued use of non-English materials in the disciplines of the humanities included in this study and would argue for the continued collecting of non-English materials by research libraries.

A second finding is that, although the number of foreign citations has not declined over time, the percentage of foreign citations over total citations has declined because of the large increases in total number of citations per article, especially in 1982 and 2002. Thus, use of foreign citations is not keeping pace with the increase in use of English citations. There are a number of possible explanations for this result. One explanation could be that fewer foreign sources are available because either fewer are being published or libraries are purchasing fewer. Another possibility is that scholars, though still using foreign resources, are less fluent than previous scholars were and therefore do not seek out those sources as often as they do English resources. It also could be that the num- ber of resources in English that are being published has increased dramatically. All of these suggested explanations would be fruitful grounds for further research.

Another interesting result of this study is the finding that German and French remain the most important non-English languages of scholarship for the humanities. As with the citation analysis in the Hutchins, Pargeter, and Saunders study, this study found that German was more often cited than French. ${ }^{27}$ The percentages for German, French, and Spanish are slightly lower in this study than in the Hutchins, Pargeter, and Saunders study, but the percentage for Italian is higher. The four fields examined in the present study were all included in the earlier study's grouping of humanities departments, but the Hutchins, Pargeter, and Saunders study also included biblical studies, English language and literature, and music. This could have contributed to the difference in frequency of cited language and illustrates the difficulty of drawing conclusions based on groupings of widely varying disciplines within the humanities.

The implications of the study results for cataloging and collection development needs in U.S. research libraries are worrisome, especially because of the decline in the study of German in the United States. Although comprehensive statistics for high school enrollments in German are difficult to find because of the decentralized public school system in the United States, Roger P. Minert reported a decline from 3.3 percent in 1968 to 2.7 percent in 1990 of public school students who were studying German. ${ }^{28}$ Jeremy D. Finn reported that in $1998,66.3$ percent of public schools did not offer German, 37 percent did not offer French, and only 4.7 percent did not offer Spanish. ${ }^{29}$ College German and French departments have shrunk as Spanish departments have grown. ${ }^{30}$ Those statistics hint at a possible explanation for 
the difficulties libraries seem to be having in finding qualified candidates with knowledge of German or French.

\section{Conclusion}

The purpose of this study was to discover whether humanities scholars continue to use foreign-language sources in their published work at the same level that they did forty years ago, before large declines in student foreign-language enrollments. The answer to this question has important implications for collection development and budget decisions in libraries supporting humanities scholarship. The fact that the authors found no decline in the numbers of foreign citations per article but, instead, actual increases in three of the four fields (history, linguistics, and classics) and a decline in the number of articles without any foreign citations indicates a continued use of foreign-language sources by humanities scholars in these fields. It seems, therefore, that scholars (in history, linguistics, and classics, at least) continue to recognize the importance of language to their research and manage to get the training they need, despite overall drops in language enrollment in the United States. When and how much language study humanities graduate students engage in and whether the pattern has changed in recent decades would require more in-depth study.

Citation studies of additional humanities fields would be useful. Given the disparity found in the citation practice of the fields of philosophy and classics, generalizations based on grouping humanities fields as a whole can be misleading. Studies of individual fields could provide more practically applicable information for collection development in those fields. At the same time, it would be very interesting to investigate why there are such differences in the use of foreign-language sources among fields. Analysis of additional journals in each field as well as development of a systematic method for analyzing citations in monographs would provide a more in-depth picture of the fields studied here. Investigation of other factors, such as the history and culture of each discipline and foreign publishing patterns in those fields, also would contribute to a clearer picture of scholarship in the humanities.

\section{Notes}

1. Richard Brod and Elizabeth B. Welles, "Foreign Language Enrollments in United States Institutions of Higher Education, Fall 1998," ADFL Bulletin 31 (2000): 25.

2. Brod and Bettina J. Huber, "The MLA Survey of Foreign Language Entrance and Degree Requirements, 1994-95," ADFL Bulletin 28 (1996): 34.

3. Brod and Welles, "Foreign Language Enrollments in United States Institutions of Higher Education, Fall 1998," 26.

4. Caroline Walker Bynum, “The Last Eurocentric Generation,” Perspectives 34 (1996): 4.

5. Paul Metz, "Bibliometrics: Library Use and Citation Studies," in Academic Libraries: Research Perspectives, ed. Mary Jo Lynch (Chicago: ALA, 1990), 147-48.

6. Anna H. Perrault, "The Changing Print Resource Base of Academic Libraries in the United States," Journal of Education for Library and Information Science 36 (1995): 301.

7. W. J. Hutchins, L. J. Pargeter, and W. L. Saunders, The Language Barrier: A Study in Depth of the Place of Foreign Language Materials in the Research Activity of an Academic Community (Sheffield, Eng.: University of Sheffield, Postgraduate School of Librarianship and Information Science, 1971), 96, 104-5.

8. Jennifer Wolfe Thompson, "The Death of the Scholarly Monograph in the Humanities? Citation Patterns in Literary Scholarship," Libri 52 (2002): 121-36.

9. Robert N. Broadus, "The Application of Citation Analyses to Library Collection Building," in Advances in Librarianship, ed. Melvin J. Voigt and Michael H. Harris, vol. 7 (New York: Academic 
Pr., 1977), 299-335.

10. John Cullars, "Characteristics of the Monographic Scholarship of Foreign Literary Studies by Native Speakers of English," College E Research Libraries 49 (1988): 157-70.

11. Jean-Pierre V. M. Herubel and Edward A. Goedeken, "Trends in Historical Scholarship as Evidenced in The American Historical Review: 1896-1990," Serials Review 19 (1993): 79-83.

12. Herubel, "The Nature of Three History Journals: A Citation Experiment," Collection Management 12 (1990): 57-67.

13. M. Sara Lowe, "Reference Analysis of the American Historical Review," Collection Building 22 (2003): 13-20.

14. Ylva Lindholm-Romantschuk and Julian Warner, "The Role of Monographs in Scholarly Communication: An Empirical Study of Philosophy, Sociology and Economics," Journal of Documentation 52 (1996): 389-404.

15. Michael Bowman, "Format Citation Patterns and Their Implications for Collection Development in Research Libraries," Collection Building 11 (1991-1992): 2-8.

16. Benny Ray Tucker, "Characteristics of the Literature Cited by Authors of the Transactions of the American Philological Association, 1956 and 1957" (Master's thesis, University of North Carolina, 1959).

17. Lowe, "Reference Analysis of the American Historical Review."

18. Herubel and Goedeken, "Trends in Historical Scholarship as Evidenced in the American Historical Review."

19. ISI Web of Knowledge, “Journal Citation Reports, Social Sciences Edition 2002," June 2003. Available online from www.isinet.com. [Accessed 28 August 2003.]

20. Hans E. Bynagle, Philosophy: A Guide to the Reference Literature, 2nd ed. Reference Sources in the Humanities Series, ed. James Rettig (Englewood, Colo.: Libraries Unlimited, Inc., 1997), 184.

21. Cullars, "Journals of the Century in Philosophy," The Serials Librarian 39 (2000): 39-58.

22. Anna L. DeMiller, Linguistics: A Guide to the Reference Literature, 2nd ed. Reference Sources in the Humanities Series, ed. James Rettig (Englewood, Colo.: Libraries Unlimited, Inc., 2000), 116.

23. A. J. Nederhof and R. A. Zwaan, "Quality Judgments of Journals as Indicators of Research Performance in the Humanities and the Social and Behavioral Sciences," Journal of the American Society for Information Science 42 (1991): 332-40.

24. Fred W. Jenkins, Classical Studies: A Guide to the Reference Literature. Reference Sources in the Humanities Series, ed. James Rettig (Englewood, Colo.: Libraries Unlimited, 1996), 186. tion."

25. Lindholm-Romantschuk and Warner, "The Role of Monographs in Scholarly Communica-

26. Jean Susorney Wellington, com., Dictionary of Bibliographic Abbreviations Found in the Scholarship of Classical Studies and Related Disciplines (Westport, Conn.: Greenwood, 1983).

27. Hutchins, Pargeter, and Saunders, The Language Barrier, 106.

28. Roger P. Minert, "Factors Influencing Enrollment in Public High School German Courses: Results of a National Survey," Unterrichtspraxis 25 (1992): 183.

29. Jeremy D. Finn, "Taking Foreign Languages in High School," Foreign Language Annals 31 (1998): 304.

30. Brod, "A Forecast for Tertiary Foreign-Language Education in the United States," Forum for Modern Language Studies 37 (2001): 375 